\title{
Cultivation of marine shrimp in biofloc technology (BFT) system under different water alkalinities
}

\author{
Piérri, $V^{a *}$, Valter-Severino, D. ${ }^{a}$, Goulart-de-Oliveira, K. $^{a}$, Manoel-do-Espírito-Santo, C. ${ }^{a}$, \\ Nascimento-Vieira, F. ${ }^{a}$ and Quadros-Seiffert, $W^{a}$
}

${ }^{a}$ Laboratório de Camarões Marinhos, Beco dos Coroas, 503, Barra da Lagoa, CP 10.136, CEP 88061-600, Florianópolis, SC, Brazil

*e-mail: viniciuspierri87@gmail.com

Received: September 13, 2013 - Accepted: April 11, 2014 - Distributed: 31/08/15

With 2 figures

\begin{abstract}
The aim of this study was to evaluate the influence of different levels of alkalinity for the superintensive cultivation of marine shrimp Litopenaeus vannamei in biofloc system. A total of 12 experimental circular units of 1000L were used supplied with $850 \mathrm{~L}$ water from a nursery, populated at a density of 165 shrimps. $\mathrm{m}^{-3}$ and average weight of $5.6 \mathrm{~g}$. The treatments, in triplicate, consisted in four levels of alkalinity in the water: 40, 80, 120 and $160 \mathrm{mg} . \mathrm{L}^{-1}$ of calcium carbonate. To correct the alkalinity was used calcium hydroxide $(\mathrm{CaOH})$. It was observed a decrease in $\mathrm{pH}$ of the water in the treatments with lower alkalinity $(\mathrm{p}<0.05)$. The total suspended settleable solids were also lower in the treatment of low alkalinity. No significant difference was observed in other physico-chemical and biological parameters in the water quality assessed, as well as the zootechnical parameters of cultivation between treatments $(\mathrm{p} \geq 0.05)$. The results of survival and growth rate of shrimps were considered suitable for the cultivation system used in the different treatments. The cultivation of marine shrimp Litopenaeus vannamei in biofloc at density of 165 shrimps. $\mathrm{m}^{-3}$ can be performed in waters with alkalinity between 40 and $160 \mathrm{mg} \cdot \mathrm{L}^{-1}$ of $\mathrm{CaCO}_{3}$, without compromising the zootechnical indexes of cultivation.
\end{abstract}

Keywords: Litopenaeus vannamei, heterotrophic cultivation, calcium hydroxide, calcium carbonate.

\section{Cultivo de camarões marinhos em sistema de bioflocos (BFT) sob diferentes alcalinidades da água}

\begin{abstract}
Resumo
O objetivo deste trabalho foi avaliar a influência de diferentes níveis de alcalinidade para o cultivo do camarão marinho Litopenaeus vannamei em sistema superintensivo em bioflocos. Foram utilizadas 12 unidades experimentais circulares de $1000 \mathrm{~L}$ abastecido com $850 \mathrm{~L}$ de água provenientes de um berçário intensivo, povoadas a uma densidade de 165 camarões. $\mathrm{m}^{-3}$ e peso médio 5,6g. Os tratamentos em triplicata consistiram de quatro níveis de alcalinidade na água: 40, 80, 120 e $160 \mathrm{mg} \cdot \mathrm{L}^{-1}$ de carbonato de cálcio. Para correção da alcalinidade, foi utilizado cal hidratada $(\mathrm{CaOH})$. Foi observado um decréscimo no $\mathrm{pH}$ da água nos tratamentos de menor alcalinidade $(\mathrm{p}<0,05)$. Os sólidos suspensos sedimentáveis totais também foram menores nos tratamentos de menor alcalinidade. Não foi observada diferença significativa nos demais parâmetros físico-químicos e biológicos de qualidade de água avaliados, assim como nos parâmetros zootécnicos do cultivo entre os tratamentos $(\mathrm{p} \geq 0,05)$. Os resultados de sobrevivência e taxa de crescimento dos camarões foram considerados adequados para o sistema de cultivo utilizado nos distintos tratamentos. $\mathrm{O}$ cultivo do camarão marinho Litopenaeus vannamei em bioflocos na densidade de 165 camarões. $\mathrm{m}^{-3}$ pode ser realizado em águas com alcalinidade entre 40 a $160 \mathrm{mg} . \mathrm{L}^{-1}$ de $\mathrm{CaCO}_{3}$, sem comprometer os índices zootécnicos do cultivo.
\end{abstract}

Palavras-chave: Litopenaeus vannamei, cultivo heterotrófico, hidróxido de cálcio, carbonato de cálcio.

\section{Introduction}

The production in biofloc system without water renewal, known as ZEAH system (Zero Exchange Aerated Heterotrophic culture system), is able to work with high productivity rates and utilizes a renewal of low or no water, reducing the risk of contamination both of cultivated area as the current environment. This technology is characterized by high concentrations of nutrients, bacteria, phytoplankton and protozoa (Burford et al., 2003) and it was designed 
to make the most of the food supplied to shrimps, where all the wastes, feces and metabolites are transformed into bacterial biomass (Avnimelech, 1999).

In cultivation without water exchange are reported low concentrations of ammonia and nitrite in the culture environment (Mcintosh et al., 2000; Burford et al., 2004; Vinatea et al., 2010), resulting from the removal of these compounds by the microbial community, which can be accomplished: a) by heterotrophic bacteria, which convert ammonia to microbial biomass; b) through conversion performed by autotrophic bacteria from ammonia to nitrate; or c) made by photoautotrophic assimilation of microalgae (Ebeling et al., 2006a).

When the nitrifying bacteria oxidize ammonium to nitrate, they also reduce the level of alkalinity in the form of carbonates and bicarbonates (Chen et al., 2006). The consumption of alkalinity as a carbon source is an important aspect in systems with limited water exchange, making it necessary to add carbonates (Ebeling et al., 2006b). However, few studies have been reported regarding the alkalinity of shrimp farming in biofloc system.

The aim of this study was to evaluate the influence of different levels of alkalinity for the cultivation of marine shrimp Litopenaeus vannamei (Boone, 1931) in superintensive system in biofloc.

\section{Material and Methods}

\subsection{Study site}

The experiment was conducted at the premises of the Laboratório de Camarões Marinhos of Universidade Federal de Santa Catarina (LCM - UFSC) located in Barra da Lagoa, Florianopolis, Santa Catarina, Brazil (latitude $27^{\circ} 35^{\prime}$ south - longitude $48^{\circ} 32^{\prime}$ west).

\subsection{Biological material}

Juveniles with an average weight of 5.6 grams were used from an intensive nursery with biofloc system under a density of 833 shrimps. ${ }^{-3}$.

\subsection{Experimental conditions}

The shrimps were stocked to a density of 165 shrimps. $\mathrm{m}^{-3}$ in 12 experimental circular units of fiberglass with $850 \mathrm{~L}$ of water from the nursery tank with previously fertilized water. Each experimental unit was equipped with an aeration system, which was connected by hoses and pipes of PVC to the central aeration system from the own laboratory, consisting of an air blower of $7.5 \mathrm{cv}$. The temperature was maintained between 29 and $29.5^{\circ} \mathrm{C}$ with the aid of titanium electric heaters of $1000 \mathrm{~W}$ of power coupled to a thermostat.

Four treatments in triplicate were used, and kept different alkalinities:

- Treatment 1 - Alkalinity at $40 \mathrm{mg} \cdot \mathrm{L}^{-1}$ of $\mathrm{CaCO}_{3}$;

- Treatment 2 - Alkalinity at $80 \mathrm{mg} \cdot \mathrm{L}^{-1}$ of $\mathrm{CaCO}_{3}$;

- Treatment 3 - Alkalinity at $120 \mathrm{mg} \cdot \mathrm{L}^{-1}$ of $\mathrm{CaCO}_{3}$;
- Treatment 4 - Alkalinity at $160 \mathrm{mg} \cdot \mathrm{L}^{-1}$ of $\mathrm{CaCO}_{3}$.

Initially, the acclimation step was performed, which was awaited the isolation of alkalinity until all the tanks reached alkalinity of 100; from this moment, the tanks were acclimated with calcium hydroxide until reaching the different treatments on the same date.

The alkalinity was controlled within the range established using calcium hydroxide to adjust the alkalinity of the treatments, with a tolerance of $10 \mathrm{mg} . \mathrm{L}^{-1}$ for more or less.

The total suspended solids of the water were kept below $850 \mathrm{mg} \cdot \mathrm{L}^{-1}$. For this, conical decanters were used with volume of $170 \mathrm{~L}$ ( $20 \%$ of total water volume) which in batches, for three consecutive days, were responsible for removing excess solid in experimental units.

The shrimps were fed three times a day with commercial feed trademark Guabi ${ }^{\circledR}(35 \%$ crude protein) with the aid of a feeder per experimental unit for adjusting the consumption.

\subsection{Analysis of water quality parameters}

The dissolved oxygen and the water temperature of the treatments were monitored with an oxygen meter YSI model 55 . The salinity was measured with a conductivity meter YSI model 30.

The water transparency and the settleable solids were measured with a Secchi disc and cone Inhoff, respectively. For the $\mathrm{pH}$, it was used a digital $\mathrm{pHmeter}$ Alfakit AT350 by electrometric method.

The concentration of total suspended solids (TSS) was evaluated following the method of volatilization gravimetry adapted from Strickland and Parsons (1972). Micro fiberglass filters were used (GF/50-A $47 \pm 0.5 \mathrm{~mm}$ ), previously dried and weighed, in the filtration of a sample volume of $100 \mathrm{~mL}$, which subsequently led to the incubator $\left(60^{\circ} \mathrm{C}\right)$ for 12 hours and then weighed on an analytical scale. They were then taken to muffle $\left(450^{\circ} \mathrm{C}\right)$ for 1 hour and 30 minutes and weighed on an analytical scale to determine the volatile suspended solids (VSS) and fixed suspended solids (FSS).

Concentrations of ammonia $\left(\mathrm{NH}_{4}^{+} / \mathrm{NH}_{3}\right)$ - N, nitrite $\left(\mathrm{NO}_{2}\right)$ - N, nitrate $\left(\mathrm{NO}_{3}\right)$ - N, phosphate $\left(\mathrm{PO}_{4}^{3}-\mathrm{P}\right)$, were analyzed by colorimetric method according to the procedure described by Strickland and Parsons (1972).

The determination of the chlorophyll- $a$ concentration was accomplished by filtering $10 \mathrm{~mL}$ of sample of each experimental unit through micro fiberglass filters (GF/F - 25mm). The extraction of the photosynthetic pigment was made in $90 \%$ acetone $\left(\right.$ Merck $\left.^{\circledR} \mathrm{PA}\right)$ in the dark at $-18{ }^{\circ} \mathrm{C}$ for 24 hours, for later determination of chlorophyll- $a$ concentration by fluorimetry (Strickland and Parsons 1972).

The alkalinity was determined by neutralization titrimetric method (APHA, 2005).

\subsection{Biological analysis of water}

For total heterotrophic bacterial count, $1 \mathrm{~mL}$ of water was collected from the water tanks and dilution in sterile saline solution $(3 \% \mathrm{NaCl})$ serial 1:10 until dilution $10^{-5}$. Subsequently, dilutions were sow on plates of Marine 
Agar and incubated at $30^{\circ} \mathrm{C}$. After $24 \mathrm{~h}$ incubation, were quantified colony forming units (CFU).

The total nitrifying bacterial count was performed by methodology MPN (Most Probable Number) described by APHA (2005). Fifteen tubes containing $10 \mathrm{~mL}$ of the respective culture environment for bacteria oxidizing ammonia were used $\left(0.5\right.$ g.L $\mathrm{L}^{-1}\left(\mathrm{NH}_{4}\right), 1.1$ g.L. ${ }^{-1} \mathrm{Na}_{2} \mathrm{CO}_{3}$, 1.0 g.L $\mathrm{L}^{-1} \mathrm{KH}_{2} \mathrm{PO}_{4}, 0.3$ g.L $\mathrm{L}^{-1} \mathrm{MgSO}_{4} .7 \mathrm{H}_{2} \mathrm{O}, 0.2$ g.L $\mathrm{L}^{-1} \mathrm{NaCl}$, 0.03g.L $\left.\mathrm{L}^{-1} \mathrm{FeSO}_{4}, \mathrm{pH} 8.0\right)$ and nitrite $\left(0.5\right.$ g.L $\mathrm{L}^{-1} \mathrm{KNO}_{2}$, 0.1875 g.L $\mathrm{L}^{-1} \mathrm{MgSO}_{4} .7 \mathrm{H}_{2} \mathrm{O}, 1.5$ g.L $\mathrm{L}^{-1} \mathrm{NaHCO}_{3}, 0.5$ g.L $\mathrm{L}^{-1}$ $\mathrm{K}_{2} \mathrm{HPO}_{4}, 0.5$ g.L. $\mathrm{KH}_{2} \mathrm{PO}_{4}, 0.2$ g.L. ${ }^{-1} \mathrm{NaCl}, 0.0125$ g.L ${ }^{-1}$ $\mathrm{CaCl}_{2} .2 \mathrm{H}_{2} \mathrm{O}, 0.01 \mathrm{~g} . \mathrm{L}^{-1} \mathrm{FeSO}_{4} .7 \mathrm{H}_{2} \mathrm{O}, \mathrm{pH} 8.0$ ) inoculated with 10,1 and $0.1 \mathrm{~mL}$ of the samples of the experimental units, constituting five replicates for each dilution. Subsequently, the tubes were incubated at $25^{\circ} \mathrm{C}$ for 21 days to check the growth. The growth of nitrifying bacteria was detected by the decrease of the $\mathrm{pH}$ value of each tube against a control tube, with no inoculation of the sample and incubated under the same conditions.

\subsection{Analysis of zootechnical parameters}

A biometry was performed weekly to monitor the growth of shrimps.

The survival rate (\%), weekly weight gain (g/week), relative growth rate $(\%)$, feed conversion factor (FCF) and productivity were calculated as follows:

- Average weight $(\mathrm{g})=$ Total biomass / final number of shrimps;

- Weekly weight gain (g/week) = Gain weight / week of cultivation;

- Biomass $(\mathrm{g})$ = Final average wet weight $\mathrm{X}$ final number of shrimps;

- Productivity $(\mathrm{Kg} \mathrm{m}-2)=$ Final biomass / total area;

- Feed Conversion Factor $(\mathrm{FCF})=$ Feed consumption / final biomass;

- Survival rate $(\%)=($ Final number of shrimps / initial number of shrimps) $\times 100$.

\subsection{Statistical analyzes}

The quality and the performance parameters of animals in different treatments were subjected to analysis of repeated measure anova $(\alpha<0.05)$ considering the assumptions required for their application (have normality and homoscedasticity of the data). The other parameters were subjected to one-way ANOVA $(\alpha<0.05)$. For the parameters that were detected with significant difference, the Tukey test for separation of means was applied $(\alpha<0.05)$ (Zar 1996).

\section{Results and Discussion}

\subsection{Physico-chemical parameters of the water}

The physico-chemical parameters monitored at temperature $\left(28.5\right.$ to $\left.30.8^{\circ} \mathrm{C}\right)$ and dissolved oxygen $\left(5.00\right.$ to $\left.6.75 \mathrm{mg} . \mathrm{L}^{-1}\right)$ remained always within levels considered ideal (outside the lethal limit) for the growth of marine shrimp L. vannamei
(Van Wyk and Scarpa, 1999) throughout the experiment. Salinity was maintained at an average of $31.5 \pm 0.64 x$, varying very little over the 49 experimental days.

The alkalinity of the initial water of the experimental units had $138 \mathrm{mg} . \mathrm{L}^{-1} \mathrm{CaCO}_{3}$. After acclimatization was completed (22 days duration), the proposed treatments of alkalinities of 40, 80, 120 and $160 \mathrm{mg} \cdot \mathrm{L}^{-1} \mathrm{CaCO}_{3}$ were achieved and maintained over the next 27 days of the experiment (Figure 1). Proper maintenance of the alkalinity in the culture environment contributes to the moderation in the changes of $\mathrm{pH}$, resulting from photosynthetic and respiratory processes (Van Wyk and Scarpa, 1999).

During the acclimatization, the $\mathrm{pH}$ of the water of experimental units decreased as the alkalinity was consumed, as was reported by Chen et al. (2006) and Ebeling et al. (2006b). This decrease is related to the nitrification process as a result of consumption of alkalinity $\left(\mathrm{CaCO}_{3}\right)$ and the release of $\mathrm{CO}_{2}$ and to the environment. According to Hargreaves (1998) for each mole of ammonia oxidized, occurs the release of two hydrogen ions $\left(\mathrm{H}^{+}\right)$, explaining the drop in $\mathrm{pH}$ found in the treatments. During the experimental period (after acclimatization) the $\mathrm{pH}$ of all experimental units was stable.

The $\mathrm{pH}$ showed interaction over time (Figure 1), between treatments. From the 18th day of the experiment, the treatment's $\mathrm{pH}$ with alkalinity 40 showed a difference compared to the alkalinity treatment of $160(\mathrm{p}<0.05)$. The alkalinity treatments 80 and 120 showed no difference between any of the treatments ( $\mathrm{p} \geq 0.05$ ).

In the 37 th day of the experiment, due to high rate of total suspended solids $\left(885.6 \pm 65.6 \mathrm{mg} . \mathrm{L}^{-1}\right)$, it was necessary to remove the solid surplus. Thus, lowering the equivalent to $50.15 \pm 7.91 \%$ at the end of the process (three days) (Figure 2).

The high concentration of suspended solids facilitates the occurrence of anoxic regions in the center of large particles of microbial flakes, allowing the occurrence of denitrification within the clusters (Ebeling et al., 2006b). According to the stoichiometry displayed by Van Rijn et al. (2006), each $\mathrm{mg}$ of nitrate reduced by heterotrophic denitrification generates an increase of $3.57 \mathrm{mg}$ of $\mathrm{CaCO}_{3}$.

Upon the removal of solids, the total volume of total suspended solids was higher in tanks with higher alkalinity, but no difference between treatments.

To the settleable suspended solids, the average of treatments of alkalinity 40, 80, 120 and 160 were 21.7, 25.3, 27.0 and $32.5 \mathrm{~mL} . \mathrm{L}^{-1}$, respectively, at the time of solids removal and demonstrated interaction over time. Where treatment of alkalinity 40 was significantly lower than the other treatments $(\mathrm{p}<0.05)$, the treatments of alkalinity 80 and 120 did not differ ( $p \geq 0.05$ ), but showed differences when compared with the treatment of alkalinity 160 which was significantly higher $(p<0.05)$. Once the removal of solids was accomplished, due to the variance resulted by the management handling, the data collected after this date have not demonstrated reliable results concerning treatments, precluding confidence in the statistical analyzes after the 37 th day of the experiment. 

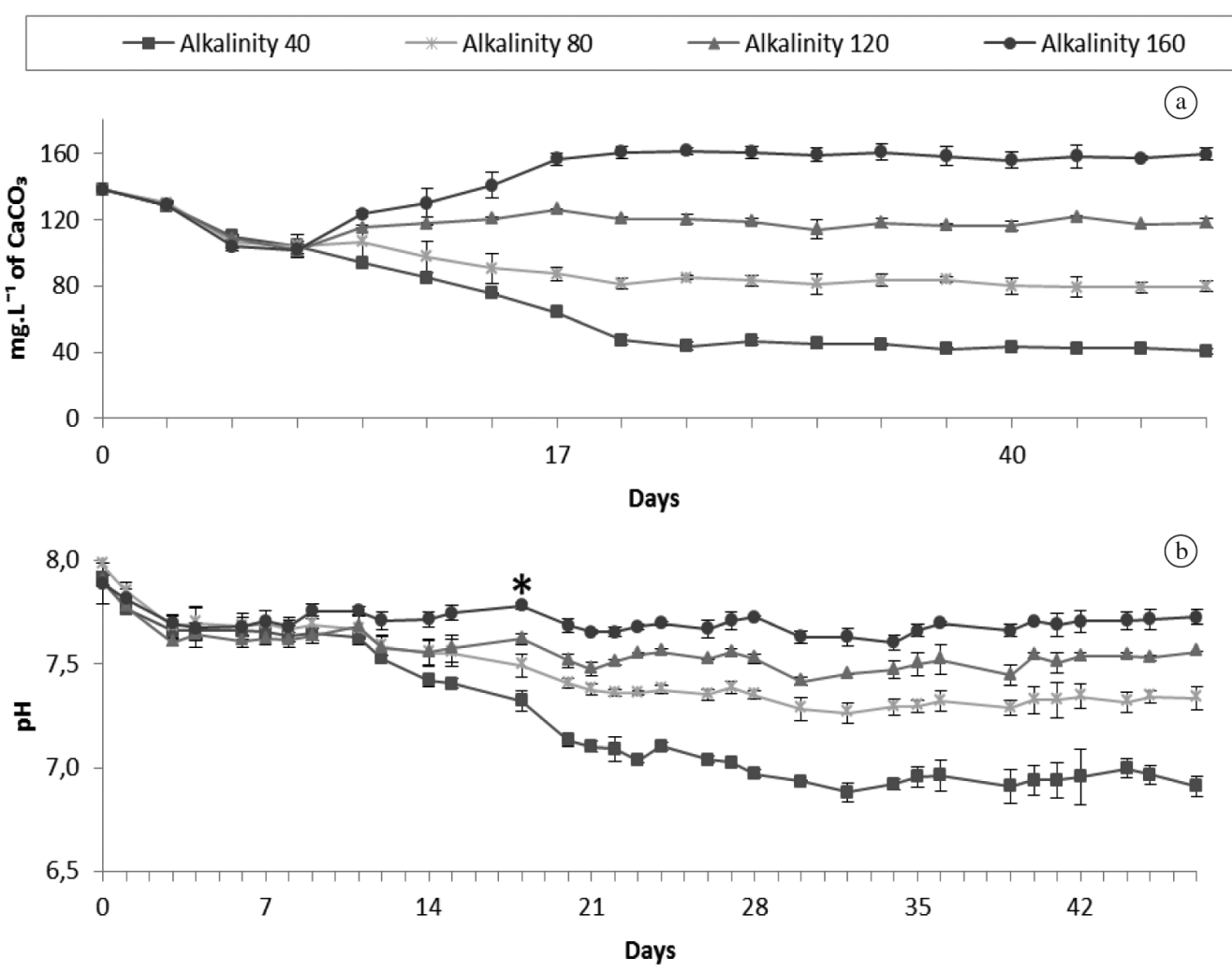

Figure 1. Variation of alkalinity (a) and $\mathrm{pH}$ (b) with standard derivation in the cultivation of marine shrimps L. vannamei in biofloc system with different alkalinities $\left(40,80,120\right.$ and $\left.160 \mathrm{mg} \cdot \mathrm{L}^{-1} \mathrm{CaCO}_{3}\right)$. ${ }^{*}$ From the 18th day, to the parameter of $\mathrm{pH}$, alkalinity treatment 40 showed differences when compared to the alkalinity treatment $160(\mathrm{p}<0.05)$. While alkalinity treatments 80 and 120 showed no difference between any of the treatments $(p \geq 0.05)$.

The higher alkalinity and $\mathrm{pH}$-value may have contributed to an increased formation of microbial aggregates, due to a higher rate of nitrification and oxidation of compounds.

Ray et al. (2010) demonstrated in their study that in the tanks where was done the removal of the suspended solids there was a $59 \%$ reduction of total suspended solids, $60 \%$ of nitrate, $61 \%$ of phosphate and a $33 \%$ increase in alkalinity. This result contrasts with the findings in this experiment, in which was not identified this increase in alkalinity after the removal of solids in the experimental units.

The ammonia was low throughout the experiment $\left(<0.4 \mathrm{mg} . \mathrm{L}^{-1}\right.$ in all treatments), the nitrite, the intermediate component of nitrification (Hargreaves, 1998), had its peak at the end of the first week of the experiment, then all readings showed nitrite values near zero $\left(<0.22 \mathrm{mg} . \mathrm{L}^{-1}\right.$ for all treatments) and both ammonia and nitrite showed no difference between treatments $(\mathrm{p} \geq 0.05)$. The low values of nitrite recorded throughout the experiment suggest the complete oxidation of ammonia to nitrate (Cohen et al., 2005).

The nitrate concentrations recorded in different experimental alkalinities were within the acceptable range ( $\leq 60 \mathrm{mg} . \mathrm{L}^{-1}$ ) for cultivation of L. vannamei (Van Wyk and Scarpa, 1999) and no significant difference was detected between treatments ( $p \geq 0.05$ ). The rates of nitrate remained stable throughout the experiment, not gradually increasing as expected, considering that nitrate is the end product of nitrification (Hargreaves, 2006). The removal of nitrate can be accomplished by the consumption of microalgae, renewals of water or use of bioreactors for the denitrification process (Hargreaves, 2006). The low values of nitrate can be connected to the low average yield of treatments (approximately $2.375 \mathrm{~kg} / \mathrm{m}^{3}$ ) and the presence of microalgae in the tanks, which are common in systems of high density and zero renewal (Burford et al., 2004).

The analysis of chlorophyll- $a$ at the end of the experiment showed the presence of algae in all tanks (mean of $0.070 \pm 0.022$ ), showing no statistical difference between treatments $(p \geq 0.05)$. The low values observed of nitrate and phosphate in the water of the tanks can be explained by the consumption of these nutrients for algae. In all tanks, the values of phosphate were consistently low. In tanks with lower alkalinity, the highest values of phosphate were observed, reaching its height to $4.03 \mathrm{mg} . \mathrm{L}^{-1}$ at the end of the experiment, while the tanks with higher alkalinity did not passed from $2.82 \mathrm{mg} . \mathrm{L}^{-1}$. But the phosphate concentrations in the present study showed no significant difference $(\mathrm{p} \geq 0.05)$. 

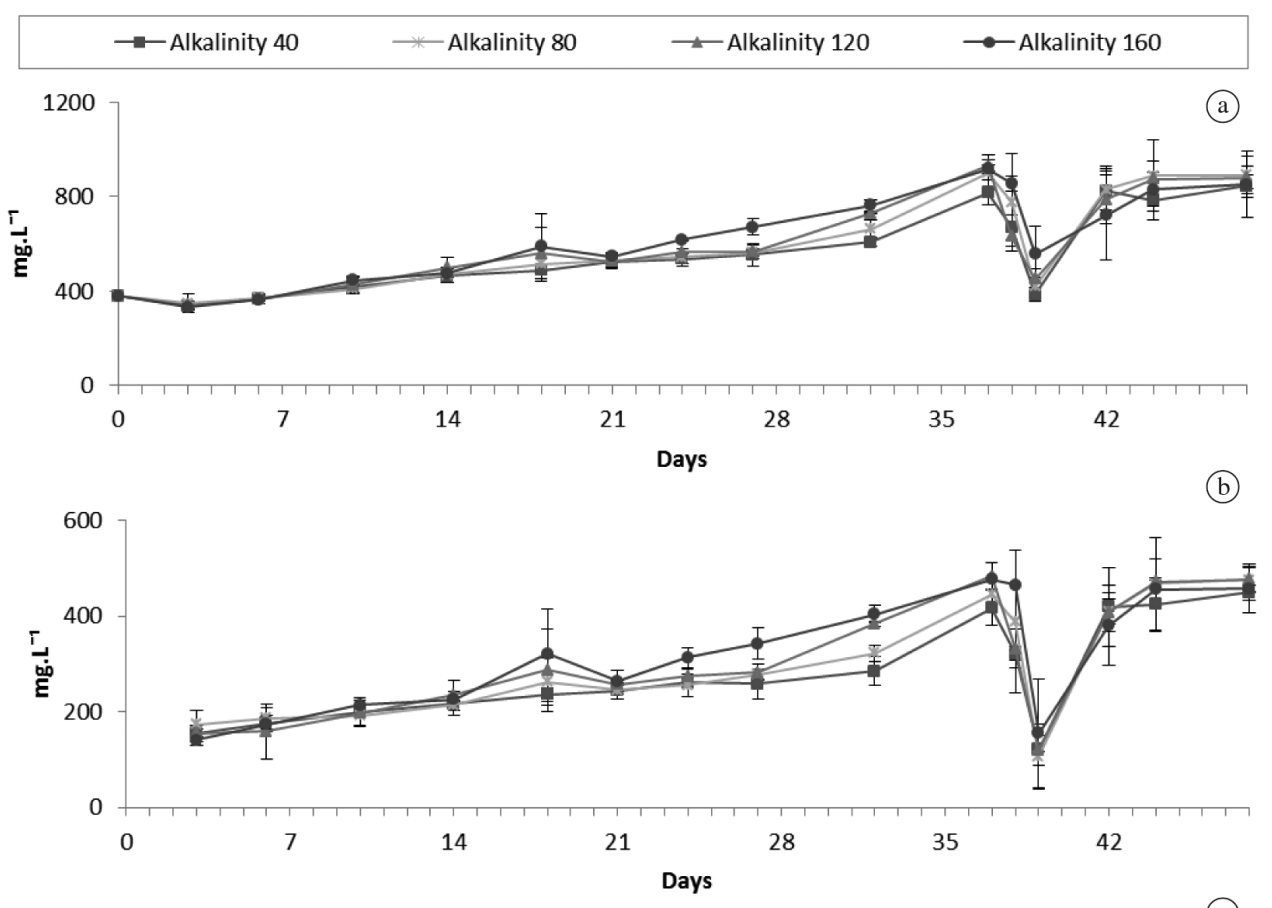

(c)

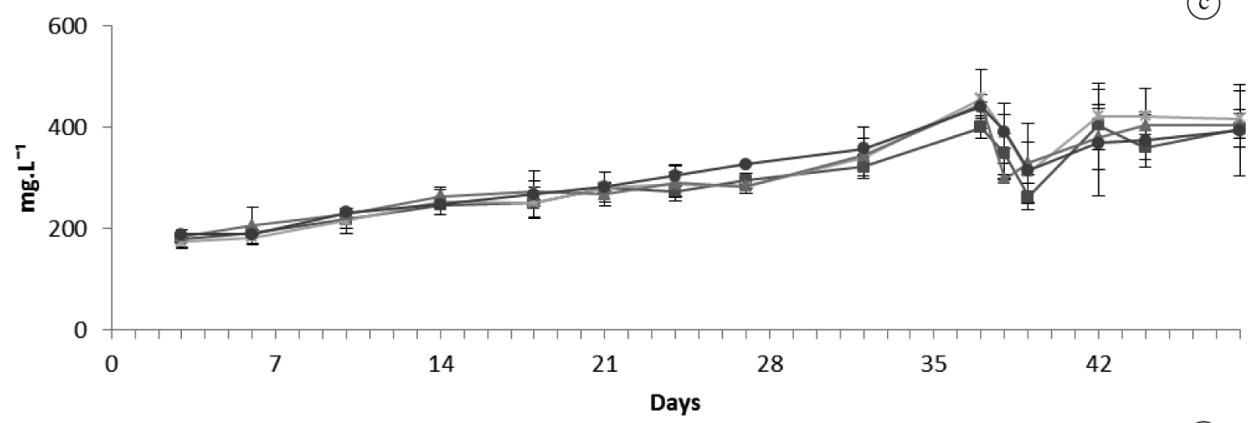

(d)

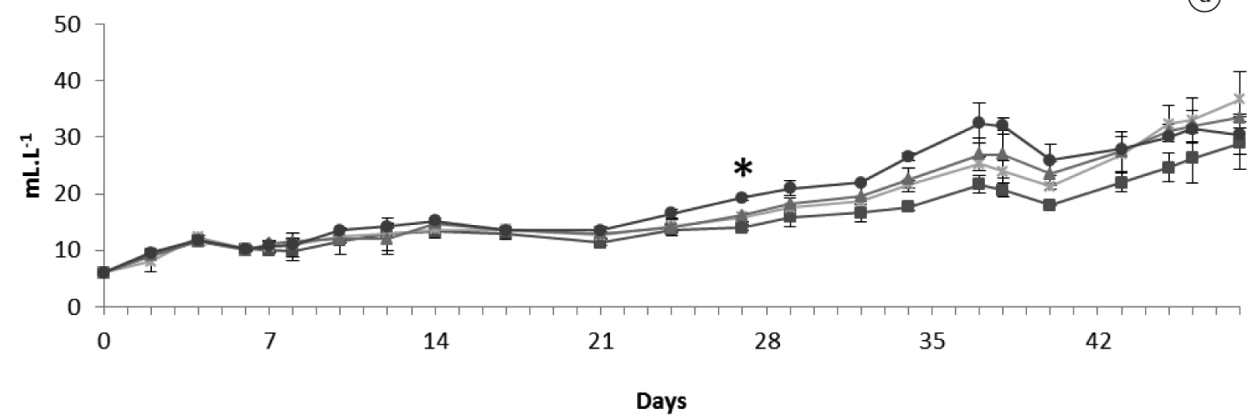

Figure 2. Variation of total suspended solids (a), fixed suspended solids (b), volatile suspended solids (c) and settleable suspended solids (d) with standard derivation in the cultivation of marine shrimps $L$. vannamei in biofloc system with different alkalinities $\left(40,80,120\right.$ and $\left.160 \mathrm{mg} \cdot \mathrm{L}^{-1} \mathrm{CaCO}_{3}\right) .{ }^{*}$ From the 27 th day, the treatments began to diverge by the parameter of settleable suspended solids until the moment of removal of solids, in which, the alkalinity treatment 40 was significantly lower than the other treatments $(\mathrm{p}<0.05)$; the alkalinity treatments 80 and 120 did not differ $(\mathrm{p} \geq 0.05)$, but showed differences when compared with the treatment of alkaline 160 which was significantly higher than the other treatments $(\mathrm{p}<0.05)$.

\subsection{Biological analysis of the water}

The final results of the total count of heterotrophic and nitrifying bacteria showed no significant difference between treatments $(\mathrm{p} \geq 0.05)$ and are presented in Table 1 .
At the end of the experiment, very similar values between treatments were observed, both for the heterotrophic bacteria count as for ammonia- and nitrite-oxidizing bacteria. These results suggest that despite the different alkalinity, there 
was no influence on the bacterial community in these culture conditions.

\subsection{Zootechnical parameters}

It was not observed differences in the parameters of final average weight, weekly weight gain (WWG), final biomass, final average productivity, feed conversion factor (FCF) and survival rate among treatments ( $\mathrm{p} \geq 0.05$ ) (Table 2).

The survival and growth rates recorded in all treatments in this experiment were within the range reported in other superintensive crops without renewal of water (Decamp et al., 2003, 2007; McIntosh et al., 2000; Neal et al., 2010; Samocha et al., 2007).

The feed conversion rates obtained in this study were similar between treatments, they were not influenced by different alkalinities and are similar to those obtained by
McIntosh et al. (2000), Neal et al. (2010) and Samocha et al. (2007).

The productivity values are lower than other studies, whereas good results of productivity are found as $7,5 \mathrm{~kg} / \mathrm{m}^{3}$ and $10,3 \mathrm{~kg} / \mathrm{m}^{2}$ (Otoshi et al., 2008), however this study used a lower density when dealing with shrimp culture in biofloc (165 cam.m $\left.\mathrm{m}^{-3}\right)$.

The results showed confront other authors like Ebeling et al. (2006b) who reported that in systems with limited water exchange, the alkalinity should be between 100-150 mg.L $\mathrm{L}^{-1}$ of $\mathrm{CaCO}_{3}$. Van Wyk and Scarpa (1999), on the other hand, reported that the $L$. vannamei needs alkalinity values above $100 \mathrm{mg} \cdot \mathrm{L}^{-1}$ of $\mathrm{CaCO}_{3}$ for its proper development, while for Boyd and Tucker (1998) the ideal alkalinity must be greater than $75 \mathrm{mg} . \mathrm{L}^{-1}$ of $\mathrm{CaCO}_{3}$.

Table 1. Mean values and standard deviation of the microbiological analysis of total count of heterotrophic bacteria quantified in colony forming units (CFU), ammonia-oxidizing bacteria (AOB) and nitrite-oxidizing bacteria (NiOB) quantified in most probable number (MPN) of water in the cultivation of marine shrimp L. vannamei in biofloc system with different alkalinities (40, 80, 120 and $\left.160 \mathrm{mg} \cdot \mathrm{L}^{-1} \mathrm{CaCO}_{3}\right)$.

\begin{tabular}{|c|c|c|c|c|}
\hline \multirow{2}{*}{ Analysis } & \multicolumn{4}{|c|}{ Treatment } \\
\hline & Alkalinity 40 & Alkalinity 80 & Alkalinity 120 & Alkalinity 160 \\
\hline Marine & & & & \\
\hline (CFU.mL ${ }^{-1}$ ) & $5,97 \cdot 10^{5} \pm 6,56 \cdot 10^{4 a}$ & $1,17 \cdot 10^{6} \pm 7,60 \cdot 10^{5 a}$ & $7,40.10^{5} \pm 1,56 \cdot 10^{5}$ & $7,85 \cdot 10^{5} \pm 3,04 \cdot 10^{5 a}$ \\
\hline MPN AOB & & & & \\
\hline$\left(\mathrm{MPN} .100 \mathrm{~mL}^{-1}\right)$ & $23 \pm 0^{a}$ & $23 \pm 0^{a}$ & $20,5 \pm 3,54^{a}$ & $28 \pm 7,07^{\mathrm{a}}$ \\
\hline MPN NiOB & & & & \\
\hline (MPN.100mL $\left.\mathrm{mL}^{-1}\right)$ & $13,50 \pm 5,77^{a}$ & $14,60 \pm 7,73^{a}$ & $10,40 \pm 3,68^{a}$ & $8,75 \pm 6,01^{a}$ \\
\hline
\end{tabular}

Values with the same letter $\left.{ }^{(a}\right)$ showed no significant difference between treatments $(\mathrm{p} \geq 0.05)$.

Table 2. Data from final average weight, weekly weight gain (WWG), productivity, feed conversion factor (FCF) and survival with standard derivation in the cultivation of marine shrimp $L$. vannamei in biofloc system with different alkalinities $\left(40,80,120\right.$ and $160 \mathrm{mg} . \mathrm{L}^{-1}$ of $\left.\mathrm{CaCO}_{3}\right)$.

\section{Treatment}

\begin{tabular}{|c|c|c|c|c|}
\hline & & & & \\
\hline & Alkalinity 40 & Alkalinity 80 & Alkalinity 120 & Alkalinity 160 \\
\hline $\begin{array}{c}\text { Final average weight } \\
\text { (g) }\end{array}$ & $15,26 \pm 0,40^{\mathrm{a}}$ & $15,19 \pm 0,39^{a}$ & $14,40 \pm 0,28^{a}$ & $14,76 \pm 0,81^{\mathrm{a}}$ \\
\hline $\begin{array}{l}\text { Weekly weight gain } \\
\text { (g) }\end{array}$ & $1,38 \pm 0,06^{\mathrm{a}}$ & $1,37 \pm 0,06^{\mathrm{a}}$ & $1,25 \pm 0,04^{\mathrm{a}}$ & $1,30 \pm 0,10^{\mathrm{a}}$ \\
\hline $\begin{array}{l}\text { Productivity } \\
\qquad \mathrm{Kg} \cdot \mathrm{m}^{-3}\end{array}$ & $2381,6 \pm 80,0^{\mathrm{a}}$ & $2404,3 \pm 62,3^{a}$ & $2363,5 \pm 58,2^{a}$ & $2352,4 \pm 117,3^{\mathrm{a}}$ \\
\hline Feed conversion factor & $1,95 \pm 0,10^{\mathrm{a}}$ & $1,95 \pm 0,07^{\mathrm{a}}$ & $2,00 \pm 0,08^{a}$ & $1,94 \pm 0,10^{\mathrm{a}}$ \\
\hline $\begin{array}{c}\text { Survival } \\
(\%)\end{array}$ & $94,76 \pm 3,38^{a}$ & $96,19 \pm 4,86^{a}$ & $99,65 \pm 0,50^{\mathrm{a}}$ & $96,79 \pm 0,50^{\mathrm{a}}$ \\
\hline
\end{tabular}

Values with the same letter $\left.{ }^{(a}\right)$ showed no significant difference between treatments $(p \geq 0.05)$. 


\section{Conclusion}

The cultivation of marine shrimp Litopenaeus vannamei in biofloc at density of 165 shrimps. $\mathrm{m}^{3}$ can be performed in waters with alkalinity between 40 and $160 \mathrm{mg} . \mathrm{L}^{-1}$ of $\mathrm{CaCO}_{3}$, without compromising the zootechnical indexes of cultivation.

\section{References}

American Public Health Association - APHA, 2005. Standard methods for the examination of water and waste water. $21 \mathrm{st}$ ed. Washington, DC: APHA. 1368 p.

AVNIMELECH, Y., 1999. Carbon nitrogen ratio as a control element in aquaculture systems. Aquaculture, vol. 176, no. 3-4, p. 227-235. http://dx.doi.org/10.1016/S0044-8486(99)00085-X.

BOYD, CE. and TUCKER, CS., 1998. Pond aquaculture water quality management. Boston: Kluwer Academic. 700 p.

BURFORD, MA., THOMPSON, PJ., MCINTOSH, RP., BAUMAN, RH. and PEARSON, DC., 2003. Nutrient and microbial dynamics in high-intensity, zero-exchange shrimp ponds in Belize. Aquaculture, vol. 219 , no. $1-4$, p. 393-411. http://dx.doi.org/10.1016/S00448486(02)00575-6.

BURFORD, MA., THOMPSON, PJ., MCINTOSH, RP., BAUMAN, RH. and PEARSON, DC., 2004. The contribution of flocculated material to shrimp (Litopenaeus vannamei) nutrition in a highintensity, zero-exchange system. Aquaculture, vol. 232, no. 1-4, p. 525-537. http://dx.doi.org/10.1016/S0044-8486(03)00541-6.

CHEN, SL., LING, J. and BLANCHETON, JP., 2006. Nitrification kinetics of biofilm as affected by water quality factors. Aquacultural Engineering, vol. 34, no. 3, p. 179-197. http://dx.doi.org/10.1016/j. aquaeng.2005.09.004.

COHEN, JM., SAMOCHA, TM., FOX, JM., GANDY, RL. and LAWRENCE, AL., 2005. Characterization of water quality factors during intensive raceway production of juvenile Litopenaeus vannamei using limited discharge and biosecure management tools. Aquacultural Engineering, vol. 32, no. 3-4, p. 425-442. http://dx.doi.org/10.1016/j.aquaeng.2004.09.005.

DECAMP, O., CODY, J., CONQUEST, L., DELANOY, G. and TACON, AGJ., 2003. Effect of salinity on natural community and production of Litopenaeus vannamei (Boone, 1931), within experimental zero-water exchange culture systems. Aquaculture Research, vol. 34, no. 4, p. 345-355. http://dx.doi.org/10.1046/ j.1365-2109.2003.00842.x.

DECAMP, O., CONQUEST, L., CODY, J., FORSTER, I. and TACON, AGJ., 2007. Effect of shrimp stocking density on sizefractionated phytoplankton and ecological groups of ciliated protozoa within zero-water exchange shrimp culture systems. Journal of the World Aquaculture Society, vol. 38, no. 3, p. 395-406. http://dx.doi.org/10.1111/j.1749-7345.2007.00111.x.

EBELING, JM., RISHEL, KL., WELSH, CF. and TIMMONS, MB., 2006a. Impact of the carbon/nitrogen ratio on water quality in zero-exchange shrimp production systems. In Proceedings of International Conference Recirculating Aquaculture, 2006. Virginia. Virginia: Virginia Tech University. p. 361-369.

EBELING, JM., TIMMONS, MB. and BISOGNI, JJ., $2006 \mathrm{~b}$. Engineering analysis of the stoichiometry of photoautotrophic, autotrophic, and heterotrophic removal of ammonia-nitrogen in aquaculture systems. Aquaculture, vol. 257, no. 1-4, p. 346-358. http://dx.doi.org/10.1016/j.aquaculture.2006.03.019.
HARGREAVES, JA., 1998. Nitrogen biogeochemistry of aquaculture ponds. Aquaculture, vol. 166, no. 3-4, p. 181-212. http://dx.doi.org/10.1016/S0044-8486(98)00298-1.

HARGREAVES, JA., 2006. Photosynthetic suspended-growth systems in aquaculture. Aquacultural Engineering, vol. 34, no. 3, p. 344-363. http://dx.doi.org/10.1016/j.aquaeng.2005.08.009.

MCINTOSH, D., SAMOCHA, TM., JONES, ER., LAWRENCE, AL., MCKEE, DA., HOROWITZ, S. and HOROWITZ, A., 2000. The effect of a commercial bacterial supplement on the highdensity culturing of Litopenaeus vannamei with a low-protein diet in an outdoor tank system and no water exchange. Aquacultural Engineering, vol. 21, no. 3, p. 215-227. http://dx.doi.org/10.1016/ S0144-8609(99)00030-8.

NEAL, RS., COYLE, SD., TIDWELL, JH. and BOUDREAU, BM., 2010. Evaluation of stocking density and light level on the growth and survival of the pacific white shrimp, Litopenaeus vannamei, reared in zero-exchange systems. Journal of the World Aquaculture Society, vol. 41, no. 4, p. 533-544. http://dx.doi. org/10.1111/j.1749-7345.2010.00393.x.

OTOSHI, CA., NAGUWA, SS., FALESCH, FC., MCCROREY, EA., ANSON, TR. and MOSS, SM., 2008. Comercial-scale production of Pacific white shrimp Penaeus Litopenaeus vannamei in a biosecure, super-intensive, recirculating aquaculture system. In Abstracts of Aquaculture America, 2008. Florida, USA. Florida: Lake Buena Vista. p. 9-12.

RAY, AJ., LEWIS, BL., BROWDY, CL. and LEFFLER, JW., 2010. Suspended solids removal to improve shrimp (Litopenaeus vannamei) production and an evaluation of a plant-based feed in minimal-exchange, superintensive culture systems. Aquaculture, vol. 299, no. 1-4, p. 89-98. http://dx.doi.org/10.1016/j. aquaculture.2009.11.021.

SAMOCHA, TM., PATNAIK, S., SPEED, M., ALI, AM., BURGER, JM., ALMEIDA, RV., AYUB, Z., HARISANTO, M., HOROWITZ, A. and BROCK, DL., 2007. Use of molasses as carbon source in limited discharge nursery and grow-out systems for Litopenaeus vannamei. Aquacultural Engineering, vol. 36, no. 2, p. 184-191. http://dx.doi.org/10.1016/j.aquaeng.2006.10.004.

STRICKLAND, JDH. and PARSONS, TR., 1972. A practical handbook of seawater analysis. 2nd ed. Ottawa: Queen`s Printer. $310 \mathrm{p}$.

VAN RIJN, J., TAL, Y. and SCHREIER, HJ., 2006. Denitrification in recirculating systems: theory and applications. Aquacultural Engineering, vol. 34, no. 3, p. 364-376. http://dx.doi.org/10.1016/j. aquaeng.2005.04.004.

VAN WYK, P. and SCARPA, J., 1999. Water quality and management. In VAN WYK, P., DAVIS-HODGKINS, M., LARAMORE, R., MAIN, KL., MOUNTAIN, J. and SCARPA, J. (Eds.). Farming marine shrimp in recirculating freshwater systems. Tallahassee: Florida Department of Agriculture and Consumer Services. p. 128-138.

VINATEA, LA., GALVEZ, AO., BROWDY, CL., STOKES, A., VENERO, J., HAVEMAN, J., LEWIS, BL., LAWSON, A., SHULER, A. and LEFFLER, JW., 2010. Photosynthesis, water respiration and growth performance of Litopenaeus vannamei in a super-intensive raceway culture with zero water exchange: Interaction of water quality variables. Aquacultural Engineering, vol. 42, no. 1, p. 17-24. http://dx.doi.org/10.1016/j. aquaeng.2009.09.001.

ZAR, JH., 1996. Biostatistical analysis. 3rd ed. Upper Saddle River: Prentice Hall. 718 p. 